\title{
METAFORA KONSEPTUAL CINTA DALAM LIRIK LAGU TAYLOR SWIFT: KAJIAN SEMANTIK KOGNITIF
}

\author{
Irwansyah \\ Fakultas Ilmu Budaya, Universitas Padjadjaran \\ irwansyah18001@mail.unpad.ac.id \\ Wagiati \\ Fakultas Ilmu Budaya, Universitas Padjadjaran \\ wagiati@unpad.ac.id \\ Nani Darmayanti \\ Fakultas Ilmu Budaya, Universitas Padjadjaran \\ n.darmayanti@unpad.ac.id
}

\begin{abstract}
Abstrak
Tulisan ini mendeskripsikan konseptualisasi metafora cinta dalam lirik lagu Taylor Swift. Metode yang digunakan ialah kualitatif deskriptif dan kajian konseptual semantik kognitif. Penggunaan bahasa kiasan kini telah merambah pada dunia tarik suara, lirik lagu secara tidak sadar mengandung penggunaan metafora yang tak terlepas pada pengalaman pribadi penulis, khususnya masalah pecintaan. Penganalisisan bertujuan untuk melihat hubungan antara sistem konseptual dan struktur semantik yang terkandung pada bahasa yang digunakan penulis yang dituangkan pada lagu-lagunya. Bedasarkan hasil penelitian yang telah dilakukan, ada beberapa konseptualisasi yang ditemukan dalam metafora bertemakan cinta, antara lain konsep cinta sebagai tangisan, konsep cinta sebagai lagu, konsep cinta sebagai benda tersembunyi, konsep cinta sebagai suatu kebutuhan, konsep cinta sebagai keindahan, konsep cinta sebagai kesempurnaan.
\end{abstract}

Kata Kunci: Metafora Konseptual, Cinta, Lagu, Taylor Swift, Semantik Kognitif

\begin{abstract}
This paper describes the conceptualization of love metaphors into the lyrics of Taylor Swift's song. The method used are descriptive qualitative and cognitive semantic conceptual approach. The use of figurative language has now penetrated in the song, song lyrics unconsciously contain the use of metaphors that cannot be separated from the author's personal experience, especially the problem of love. The aims of this research are to find the relationship between the conceptual system and the semantic structure contained in the language used by the writer as outlined in his songs. Based on the results of research, there are several conceptualizations found in love metaphors, namely the concept of love as a cry, the concept of love as a song, the concept of love as a hidden object, the concept of love as a necessity, the concept of love as a beauty, the concept of love as perfection in Taylor Swift song lyrics.
\end{abstract}

Keywords: Conceptual Metaphor, Love, Song, Taylor Swift, Cognitive Semantics

\section{PENDAHULUAN}

Manusia tidak pernah terlepas dalam kegiatan bahasa, baik bersifat verbal maupun nonverbal. Bahasa digunakan manusia untuk berkomunikasi 
satu sama lain. Penggunaan bahasa selain untuk berkomunikasi tentunya untuk mengungkapkan perasaan, ide, gagasan dan maksud dari tuturannya. Bahasa menurut Keraf (1997: 1) Bahasa adalah alat untuk berkomunikasi antar anggota masyarakat berupa simbol bunyi yang dihasilkan oleh alat ucap. Sementara itu, menurut Chaer (1994: 32) Bahasa adalah sistem lambang bunyi bersifat arbitrer digunakan oleh para anggota kelompok sosial untuk berkomunikasi, dan mengidentifikasi diri. Fungsi bahasa dijelaskan oleh Keraf (1994) dalam (Subhan, Nur, \& Nugraha, 2019) yang mengungkapkan empat poin utama yakni sebagai alat ekspresi diri, alat untuk berkomunikasi, sebagai alat untuk mengadakan integrase dan adaptasi sosial dan sebagai alat untuk mengadakan kontrol sosial. Hal ini sejalan dengan kebutuhan manusia akan manfaatnya bahasa yakni mempersatukan dan menyamakan paham untuk berkomunikasi baik verbal maupun nonverbal yang bersifat arbitrer (manasuka) dan konvensional.

Bahasa sebagai sarana komunikasi terdiri dari dua bagian yaitu bentuk (form) dan makna (meaning). Ilmu yang mengkaji makna dalam linguistik biasa disebut dengan semantik, ilmu ini memiliki peran penting dalam linguistik khususnya yang berkaitan tentang makna sehingga tidak menimbulkan beda paham antar satu dengan yang lainnya. Manusia diciptakan mempunyai pikiran yang berfungsi untuk mengatur pengetahuan yang didapat dari pengalaman hidupnya sendiri maupun pengalaman hidup orang lain disekitarnya. Pikiran atau kognisi setiap orang berbeda, bahkan pengalaman hidup seseorangpun berbeda. Pikiran tersebut kenyataannya merasuk dalam pengalaman secara langsung ataupun tidak, baik dari persepsi, gerakan tubuh, dan pengalaman fisik maupun sosial. Proses kognitif tersebut akan menghasilkan metafora.

Metafora adalah cara memperoleh suatu konsep dengan konsep lainnya melalui bahasa. Menurut Knowless dan Moon (2006) dalam (Wiradharma \& S, 2016) mengungkapkan bahwa metafora adalah suatu bahasa nonliteral untuk meyatakan perbandingan dua hal secara implisit. Untuk memahami metafora selanjutnya (Lyra, Sobarna, Djajasudarma, \& Gunardi, 2016) menyatakan ada dua pemahaman yang bisa digunakan ketika memahami metafora (1) menunjukkan suatu gaya bahasa (figure of speech) dan (2) merupakan manifestasi sistem berpikir yang terlibat pada kehidupan sehari-hari. Dengan kata lain, metafora sebuah wadah untuk menyampaikan pesan atau informasi dengan cara yang tidak langsung. Metafora terbentuk dari pengalaman, untuk menganalisis metafora bisa menggunakan pendekatan metafora konseptual.

Metafora konseptual adalah metafora yang memiliki dua ranah yakni ranah sumber dan ranah sasaran. Sementara itu, Lakoff dan Johnson (1980; 2003) mempertegas teori dan didukung oleh Konwles dan Rosamund (2006: 33) dan Kovecses (2010: 17) dalam (Meganova Lyra, 2018) metafora konseptual memiliki tiga komponen yakni, ranah sumber (source domain), ranah sasaran (target domain) dan pemetaan (correspondence or mapping). George Lakoff dan Mark Johnson adalah pencetus teori metafora konseptual, pada teori pertama yang dicetuskan oleh Lakoff dan Johnson ditulis pada sebuah buku yang berjudul Metaphors We Live By (1980). Pada bukunya, mereka berbicara tentang pengembangan teori yang mengindentifikasi bagaimana ranah sumber dan ranah target bisa 
berhubungan dengan metafora. Menurut Kovecses (2010: 4) konseptual A (ranah sasaran) dengan konseptual B (ranah sumber) disebut dengan metafora. Lakoff dan Johnson (1984: 3) dalam Yoastri (2018) mengemukakan "we have found, on the contrary, that metaphor is pervasive in everyday life, not just in language but in thought and action" (Metafora bukan hanya bahasa retorika dan puitis seperti pada umumnya, tetapi metafora melekat dengan manusia pada kehidupan sehari-hari tidak hanya dalam bahasa saja tetapi juga dalam pikiran dan aksi).

Metafora tidak hanya ditemukan pada sebuah novel, pidato, puisi saja tetapi penggunaan metafora dapat ditemukan dalam sebuah lagu. Menurut Kovecses (2002: 20) dalam (Aisah, 2010) metafora dalam lagu merupakan ekspresi emosi penyair terhadap apapun yang menyentuh hatinya dan dialami oleh kehidupannya. Sejalan dengan hal tersebut, sebuah lagu yang ditulis tentunya mengandung ekspresi pikiran, gagasan atau pendapat yang ingin di ungkapkan atas pengalaman yang dilihat maupun di dengar. Dalam mengekspresikan pengalamannya biasanya penyair menggunakan permainan kata-kata dan bahasa untuk menciptakan daya tarik terhadap lagu yang mereka buat. Teks dalam lirik lagu biasanya bersifat monolog yang mana hanya ada satu subjek (penulis) dan jarang atau bahkan tidak pernah melibatkan pihak lain untuk berbicara.

Salah satu penulis lagu yang handal dalam mengungkapkan kata-kata dalam sebuah lagu adalah Taylor Swift. Swift memulai karirnya sejak umur 14 tahun, sebagai penulis lagu Swift mendapatkan penghargaan dari Nashville Songwriters Association dan Songwriters Hall of Fame. Swift telah menulis lebih dari 100 lagu yang ia tulis berdasarkan pengalamannya sendiri, diantaranya Love story, You Belong with Me, We are Never Getting Back Together, I Knew You Were Trouble. Penulis memilih album pertama yang mengusung Taylor Swift sebagai nama album debutnya, ia dedikasikan permulaan karirnya didunia permusikan yang dirilis 2006 sebagai sumber data. Dalam album Taylor Swift milik Taylor Swift terdapat 14 lagu dan penulis hanya menggunakan beberapa lagu yang mengandung data metafora cinta. Tujuan penelitian ini ingin melihat kognisi penyanyi wanita dan penulis lagu yaitu Taylor Swift pada lagu-lagu yang ia ciptakan, melalui pendekatan metafora konseptual.

\section{METODE PENELITIAN}

Penggunaan metode ditujukan untuk menjawab permasalahan yang ada. Data yang dianalisis ialah data yang memuat metafora dalam lirik lagu Taylor Swift dalam album debut. Penelitian ini merupakan penelitian kualitatif dekriptif. Djajasudarma (2010: 11) mengungkapkan bahwa metodologi sebagai prosedur yang dapat menghasilkan data berupa deskriptif seperti data tulis ataupun lisan. Selengkapnya dijelaskan kembali oleh Djajasudarma (2010: 16) deskriptif sebagai ciri data secara akurat berdasarkan sifat alamiah.

Metode dan Teknik yang digunakan merujuk kepada teori Sudaryanto (2015: 9) metode adalah salah satu cara yang harus dilakukan, sementara teknik adalah cara mengaplikasikan atau menerapkan metode. Sudaryanto (1993) juga mengungkapkan metode prosedur pengaplikasian penelitian dengan membaginya menjadi 3 yakni, (1) penyediaan data, (2) penganalisisan data, dan 
(3) penyajian hasil (akhir). Teknik yang digunakan dalam penelitian ini ialah simak dan catat, teknik simak atau penyimakan adalah sebuah metode observasi atau mengamati. Teknik lanjutan yang digunakan pada penelitian ini adalah teknik simak bebas libat cakap (SLBC). Teknik tersebut digunakan dengan alasan peneliti tidak terlibat secara langsung. Untuk penelitian ini lebih akurat, penulis (1) membaca dan mendengarkan lirik demi lirik secara intensif, (2) mencatat penggunaan metafora dalam album Taylor Swift, (3) memilah-memilih jenis data metafora yang mengandung metafora cinta yang terkandung dalam lirik lagu Swift untuk selanjutnya disajikan berupa pembahasan.

Sumber data yang dikaji dalam album Taylor Swift yaitu Tim McGraw, Picture to Burn, Teardrops on My Guitar, A Place in This World, Cold as You, The Outside, Tied Together With A Smile, Stay Beautiful, Should've Said No, Mary's Song (Oh My My My), Our Song, I'm Only Me When I'm With You, Invisible, A Perfectly Good Heart. Lirik-lirik tersebut diakses melalui situs https://www.azlyrics.com/ untuk memudahkan analisis.

\section{HASIL PEMBAHASAN}

Bab ini memaparkan hasil dan analisis untuk menjawab permasalahan yang ada yaitu konseptualisasi metafora cinta pada lirik lagu Taylor Swift dalam album Taylor Swift debut.

\section{Konsep Cinta adalah Tangisan}

Pemetaan konseptual cinta adalah tangisan merujuk pada data berikut:

Data (1)

September was a month of tears.

'September adalah bulan tangisan'

Data (2)

He's the reason for the tearsdrops on my guitar.

'dialah (lk.) alasan tangisan di gitarku'

Ranah Sumber: tears 'tangisan'

Ranah Sasaran: love 'cinta'

Pada lirik data (1) dan (2) ditemukan bentuk metafora tears dan tearsdrops 'tangisan'. Ranah sasaran pada data ini ialah cinta dan ranah sumbernya yaitu tangisan. Ranah sumber tangisan ditransferkan kepada ranah sasaran cinta, dapat dipetakan dengan sesuatu contohnya jika kita terluka oleh benda (pisau) selain rasa sakit yang dirasa kitapun akan menangis, hal ini sejalan jika si lelaki atau cintanya melukai penutur ia akan menangis, menangisi lelaki yang ia cintai. Kalimat September was a month of tears 'September adalah bulan tangisan'. Kata September adalah bulan dimana penutur sangat terluka dan membuat penutur menangis, sebagaimana makna dari lagu tersebut bahwa penutur telah 
mengalami putus cinta dibulan September dan penutur teringat kembali kemasa lalu saat ia putus dengan kekasihnya.

Pada kalimat he's the reason for the teardrops on my guitar 'dialah (lk.) alasan tangisan di gitarku' dapat dipahami bahwa si lelaki yang ia cinta adalah salah satu alasan utama penutur menangis dan penutur menuangkan tangisan itu pada gitar. Gitar digunakan sebagai objek penutur untuk meluapkan emosi (tangisan) yang ia rasakan dan membuat objek (cinta) sebagai acuan penutur untuk membuat karya yang ia tuangkan dalam sebuah lagu.

\section{Konsep Cinta adalah Sebuah Lagu}

Data (3)

He's the song in the car I keep singing

'dia (lk.) adalah lagu dimobil yang terus saya nyanyikan'

Data (4)

Our song is slamming screen door.

'lagu kita adalah tertutupnya pintu'

Data (5)

Our song is the way you laugh

'lagu kita adalah caramu tertawa'

Data (6)

He whispers songs into my window

'dia (lk.) menyerukan lagu-lagu kejendelaku'

Ranah Sumber: song 'lagu'

Ranah Sasaran: love 'cinta'

Data (3), (4), (5), dan (6) ditemukan data yang memuat metafora konseptual yaitu konsep cinta adalah sebuah lagu. Ranah sasaran love 'cinta' dipahami oleh ranah sumber song 'lagu'. Song 'lagu' bermakna a short poem or other set of words set to music or meant to be sung. (Oxford, daring) 'puisi pendek kata lain yang diatur ke musik atau untuk dinyanyikan'. Hal ini dapat dipetakan bahwa lagu bisa menyenangkan dan menenangkan bagi seseorang yang mendengarkannya, bahkan ada sebuah lagu yang bisa membuat orang tertidur, ada pula lagu yang membuat seseorang bergoyang. Pada data ini, cinta disandingkan dengan sebuah lagu bahwa penutur memahami jika ia melantunkan, mendengarkan lagu atau musik, secara tidak sadar akan menggerakan emosi kita, lagu atau musikpun bisa membuat kita sedih, gembira bahkan bisa membuat seseorang terharu bahkan meneteskan air mata.

Lagu juga bisa memberikan pengaruh secara bagi otak dan bertanggung jawab pada aspek yaitu memori dan visual. Memori seseorang akan teringat kembali pada suatu kejadian dimana ia pernah mempunyai kenangan khusus akan sebuah lagu yang ia dengarkan bersama siapa, sementara visual akan memvisualkan gambaran kenangan yang pernah dirasakan hampir secara detail 
dari tempat, kejadian dan waktunya. Musik atau lagupun bisa menjadi kekuatan positif bagi kesehatan mental seseorang yang mendengarkannya dan bisa menjadi bagian dari musik atau lagu yang didengarnya.

\section{Konsep Cinta sebagai Benda Tersembunyi}

Data (7)

And when you find everything you looked for, I hope your life leads you back to my door 'dan ketika kamu menemukan sesuatu yang kamu cari, aku harap hidupmu membawamu kembali kepada pintuku'

Data (8)

The smiles, the flowers, everything is gone, yesterday I found out about you

Senyuman, bunga, semuanya hilang, kemarin aku menemukan kisahmu

Ranah Sumber: a hidden object 'objek tersembunyi'

Ranah Sasaran: love 'cinta

Data (7) dan (8) mengandung metafora konseptual bahwa konsep cinta sebagai benda tersembunyi yang ditekankan oleh kata find dan found. Kata found diikuti kata found out about you seakan tentang seseorang sebagai suatu benda yang tersembunyi, maksud dari konseptual ialah untuk menyampaikan bahwa cinta bukan hanya datang dengan sendiri melainkan sesuatu yang harus dicari. Found bermakna having been discovered by chance or unexpectedly 'telah ditemukan secara kebetulan atau tak terduga' (Oxford, daring).

\section{Konsep Cinta sebagai Kebutuhan}

Data (9)

And he's all that I need to fall into

'dan dia (lk.) adalah satu-satunya yang saya butuhkan.

Ranah sumber: Kebutuhan

Ranah sasaran: cinta

Data (11) mengandung metafora need 'butuh'. Konseptualisasi dari data ini konsep cinta sebagai kebutuhan. Need bermakna to require something/somebody because they are essential or very important, not just because you would like to have them 'membutuhkan sesuatu atau seseorang karena mereka penting dan sangat penting, bukan hanya karena kamu ingin memilikinya' (Oxford, daring). Hal tersebut ditransferkan dan dipahami oleh ranah sasaran cinta, bahwa penutur sangat membutuhkan seseorang yang ia sayang, cintai. Bukan hanya sekedar penting tetapi seseorang atau lelaki yang penutur maksud ialah seseorang atau lelaki yang sangat berharga untuk hidup penutur. 
Irwansyah, Wagiati, Nani Darmayanti

\section{Konsep Cinta sebagai Keindahan}

Data (10)

You're beautiful every little piece love

'kamu indah pada setiap bagian dari cinta'

Ranah Sumber: Keindahan

Ranah Sasaran: Cinta

Pada data tersebut terdapat konseptualisasi, konsep cinta sebagai keindahan. Ditandai dengan metafora beautiful dan pada kata sebelumnya ada kata you. Beautiful bermakna having beauty; pleasing to the senses or to the mind (Oxford, daring) 'memiliki kecantikan; menyenangkan indra atau pikiran'. Konsep keindahan dipahami oleh ranah sasaran cinta, yang mana pria atau lelaki yang penutur sayang atau sukai sangat menyenangkan indra dan pikiran si penutur. Bahwasannya pria atau lelaki tersebut ialah sosok yang sangat indah pada setiap inci bagian cinta yang penutur punya dan bisa dikatakan kalau si pria atau lelaki yang penutur sayang, cinta dan suka ini hampir sempurna.

\section{Konsep Cinta sebagai Kesempurnaan}

Data (11)

And there he goes so perfectly, the kind of flawless I wish I could be

'dan dia pergi begitu sempurna, kesempurnaan yang ku harap bisa kumiliki'

Data (12)

Why would you wanna break a perfectly good heart?

'mengapa kamu ingin menghancurkan sebuah hati yang sempurna?'

Ranah sumber: kesempurnaan

Ranah sasaran: cinta

Data diatas menunjukkan konseptualisasi bahwa konsep cinta sebagai kesempurnaan. Kata yang menunjukkan konsep tersebut perfectly, flawless. Flawless bermakna without flaws and therefore perfect 'tanpa kekurangan dan karenanya sempurna' sementara perfect bermakna having everything that is necessary; complete and without faults or weaknesses 'memiliki segalanya yang diperlukan; lengkap dan tanpa kesalahan atau kelemahan' (Oxford, daring). Konsep kesempurnaan dipahami oleh cinta bahwasanya penutur telah mencintai kekasihnya dengan sangat sempurna tanpa kesalahan ataupun kelemahan si lelaki, tetapi si lelaki pergi begitu sempurna dan menghancurkan hati penutur. Bisa disimpulkan segala apapun yang terlalu maka hasilnyapun akan terlalu, entah terlalu bahagia, sedih, sakit ataupun jatuh. 


\section{PENUTUP}

Metafora yang digunakan oleh seorang penulis lagu biasanya hasil dari pengalamannya sendiri, salah satunya masalah percintaannya yang setiap manusia pasti pernah merasakan bahagia, sedih, sakit pada cinta. Berdasarkan penelitian yang telah dilakukan, penulis menemukan beberapa konseptualisasi metafora bertemakan cinta pada lirik lagu Taylor Swift album debut antara lain, konsep cinta sebagai tangisan, konsep cinta sebagai lagu, konsep cinta sebagai benda tersembunyi, konsep cinta sebagai suatu kebutuhan, konsep cinta sebagai keindahan, konsep cinta sebagai kesempurnaan.

\section{DAFTAR PUSTAKA}

Abdul Chaer. (1994). Linguistik Umum. Jakarta: Rineka Cipta

Aisah, S. (2010). Metafora Dalam Lagu Iwan Fals Yang Bertemakan Kritik Sosial. Fib Ui, 1-58. Retrieved from http:/ / lib.ui.ac.id/file?file=digital/20251418RB00S200m-Metafora dalam lagu.pdf

Djajasudarma, T. F. (2010). Metode Linguistik. Bandung: PT Refika Aditama

Keraf, Gorys. (1997). Komposisi. Jakarta: Ikrar Mandiri Abadi.

Kovecses, Zoltan. (2010). Metaphor: A Practical Introduction. Edisi kedua. Oxford: Oxford University Press

Lyra, H. M., Sobarna, C., Djajasudarma, F., \& Gunardi, G. (2016). Citra Hate' Hati' dalam Metafora Orientasional dalam Bahasa Sunda. Metalingua, 14(2), 167176.

Meganova Lyra, H. (2018). Konseptualisasi Sosiokultural Masyarakat Sunda dalam Metafora Konseptual Bagian Tubuh. Metahumaniora, 8(1), 58. https:// doi.org/10.24198/mh.v8i1.18874

Subhan, R. F., Nur, T., \& Nugraha, T. C. (2019). KONSEPTUALISASI SIFAT DAN PERBUATAN DALAM METAFORA BERUNSUR TUBUH “TANGAN" PADA ALQURAN (Trait and Action Conceptualization in Metaphor of "Hand" at The Koran). Kandai, 15(1), 61. https:/ / doi.org/10.26499/jk.v15i1.1287

Sudaryanto. (1993). Metode dan Aneka Teknik Analisis Bahasa. Yogyakarta: Duta Wacana University Press

Wiradharma, G., \& S, A. T. W. (2016). Metafora Dalam Lirik Lagu Dangdut: Kajian Semantik Kognitif. Arkhais - Jurnal Ilmu Bahasa Dan Sastra Indonesia, 7(1), 5. https://doi.org/10.21009/arkhais.071.02

Yoastri, (2018). Metafora Konseptual Cinta dalam lirik lagu Ed Sheeran: Kajian Semantik Kognitif. Tesis. Jatinangor: Universitas Padjadjaran 